\title{
Utjecaj depresivnog roditelja na razvoj djeteta
}

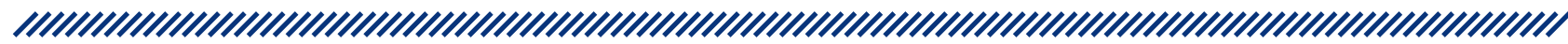

1 Boris Vučić

1 Samka Ekić

1 Klinika za psihijatriju, Klinička bolnica Dubrava, Zagreb, Hrvatska

\section{Sažetak}

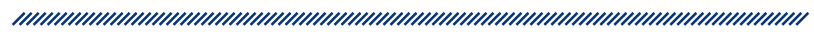

Poremećaji raspoloženja spadaju među najčešće psihijatrijske poremećaje uopće. Incidencija je depresivnog poremećaja u porastu. Depresivni poremećaj duboko prožima sve aspekte života i djeluje na cijelu obitelj, tako da možemo reći da je bolešću pojedinca pogođena cijela obitelj, posebno njezini najvulnerabilniji članovi. Budući da ne postoji dobna granica za nastanak depresije, postavlja se pitanje kako ta bolest djeluje na djecu, odnosno kakve posljedice na psihosocijalni razvoj i formiranje ličnosti ostavlja odrastanje uz depresivne roditelje.

Ključne riječi: depresivni poremećaj roditelja, psihosocijalni razvoj djeteta

Datum primitka: 15.09.2015.

Datum prihvaćanja: 17.11.2015.

Adresa za dopisivanje:

Boris Vučić, dipl. med. techn.

Klinika za psihijatriju

Klinička bolnica Dubrava

Avenija Gojka Šuška 6, 10000 Zagreb

E-pošta: borisvucic7@gmail.com

\section{Uvod}

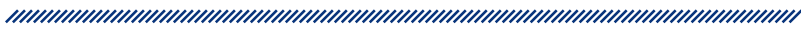

Poremećaji raspoloženja najčešći su psihijatrijski entiteti. Glavni su simptomi tih poremećaja, uz promjenu raspoloženja, poremećaj nagona, energije i kognicije. Depresivni poremećaj osim sniženog raspoloženja uključuje oskudnu emocionalnu reakciju, gubitak volje, energije, interesa, osjećaj krivnje i smetnje nagona. Često se kod osoba koje boluju od depresivnog poremećaja javljaju suicidalna razmišljanja i/ili pokušaji suicida ${ }^{1}$. Depresivni poremećaj pojavljuje se u dva oblika, kao depresivna epizoda i kao povratni depresivni poremećaj. Depresivni je poremećaj najčešći entitet ne samo unutar poremećaja raspoloženja nego i unutar svih psihijatrijskih poremećaja općenito ${ }^{1}$.

Incidencija depresivnog poremećaja u stalnom je porastu još od 1915. godine i prema Svjetskoj zdravstvenoj organizaciji do 2020. godine po učestalosti će biti na drugom mjestu svih bolesti. Rizik za obolijevanje od depresije za žene je 10 do $25 \%$, a za muškarce 5 do $12 \%{ }^{2}$.

\section{Etiologija}

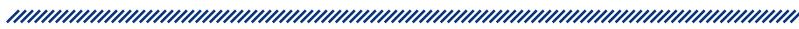

Mnoga su tumačenja o etiologiji depresivnog poremećaja. Biološka tumačenja spominju naslijeđe kao bitan čimbenik, jer depresivni bolesnik među svojim rođacima ima više osoba oboljelih od depresivnog poremećaja nego zdrava osoba ${ }^{3}$. Postoje tumačenja da se prenosi poligenski, gdje su ključni oni geni uključeni u metabo- 
lizam serotonina ${ }^{4} \mathrm{i}$ dopamina ${ }^{5}$. Analitičke teorije spominju fiksaciju na oralnu fazu razvoja ${ }^{6}$. Kognitivne teorije smatraju da depresivne misli, afekti i ponašanje mogu nastati zbog pogrešnog mišljenja i procesuiranja informacija $^{7}$, bihevioralne pokazuju da oboljeli imaju manjak socijalnih vještina ${ }^{8}$. Teorija osobina ličnosti tumači da su pasivnost, povučenost i nisko samopoštovanje put ka depresivnom poremećaju. Stresni životni događaji također su često povezani s pojavom depresivnog poremećaja9. Pojavljivanje svih bolesti i poremećaja slijedi isti put: prisutnost uzročnih čimbenika i njihov utjecaj na pojedinca dovodi do pogoršanja funkcioniranja izloženog pojedinca i osoba u njegovoj neposrednoj blizini, ovisno o postojanju rizičnih i protektivnih čimbenika $^{10}$. U ovakvoj multipliciranoj etiologiji zapravo vidimo kompleksnost ovog psihijatrijskog poremećaja.

\section{Odnos depresivnog roditelja i djeteta}

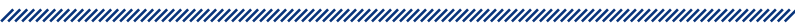

Težina i kompliciranost poremećaja nameće pitanje kakav odgoj mogu pružiti depresivni roditelji, kojima je i samima često potrebna medicinska skrb ili barem nadzor, $\mathrm{i}$ kakve to posljedice ostavlja u razvoju djeteta i u njegovoj transformaciji u odraslog čovjeka. Studije depresivnosti kod djece pozornost su usmjerile na obiteljske odnose kao moguće faktore objašnjenja depresivnostit ${ }^{11}$.

Obitelj je najznačajniji faktor socijalizacije u ranom djetetovu životu, kad se stječu prva iskustva i stavovi, stoga je odnos između roditelja i djeteta temelj za razvoj zdrave ličnosti. Čest je problem u roditeljskom odgoju transgeneracijski prijenos grešaka vlastitih roditelja i pokušaj njihova ispravljanja. Djeci treba ponuditi pravila koja će se dosljedno primjenjivati i ograničenja da bi se zadovoljila ravnoteža i formirale zdrave osobnosti. Djeca u najranijoj dobi uče oponašanjem koje je ključno za njihov razvoj te roditelji moraju biti svjesni svoje uloge u odgoju ${ }^{12}$. Postavlja se pitanje kakav odgoj s obzirom na svoje mogućnosti pruža depresivan roditelj i kakve su dalekosežne posljedice. Za nastanak poteškoća u razvoju djece od veće su važnosti obiteljski odnosi nego vrsta bolesti roditelja ${ }^{13}$.

Jedna od dvije dimenzije roditeljskog ponašanja, emocionalnost, odnosi se na emocije koje roditelj proživljava i iskazuje u odnosu s djetetom. Na jednom je kraju emocionalna toplina, a na drugom hladnoća. Dokazano je da toplina kao aspekt obiteljskog okruženja najviše utječe na dječji razvoj jer takvi roditelji podržavaju svoju djecu, ohrabruju, motiviraju i hvale, dok emocionalno hladni zanemaruju i odbacuju, kritiziraju i kažnjavaju. Druga je dimenzija kontrola, koja može biti prečvrsta te dovesti do ovisnosti, smanjene motivacije ili potisnute hostilnosti ili slaba s malo pravila, što može dovesti do pojave agresivnosti kod djeteta ${ }^{12}$. Većina studija koja proučava odnos ličnosti roditelja i kvalitete roditeljstva usmjerena je na vezu između poremećaja u psihološkom funkcioniranju i roditeljskog ponašanja. Depresivne majke stvaraju razorno, hostilno i odbacujuće okruženje svojoj djeci koje nepovoljno utječe na dječje funkcioniranje i na psihološku adaptaciju djeteta, manje su responsivne te se slabije prilagođavaju dječjim potrebama, pokazuju više ljutnje i tuge te manje pozitivnih emocija nego nedepresivne majke ${ }^{14}$. Primijećen je utjecaj na stanje afekta kod djeteta, i to bez obzira na jačinu simptoma ${ }^{15}$. Roditelji koji imaju simptome depresivnog poremećaja pokazuju i manje prihvaćanja, podrške ili emocija u odnosu s djetetom ${ }^{14}$. Smanjena je usmjerenost ka djeci i transfer pozitivnih emocija ${ }^{16}$. Općenito su značajke odnosa depresivne djece i njihovih roditelja smanjena komunikacija, povećana hostilnost te manjak zajedničkih aktivnosti ${ }^{11}$.

\section{Razvoj dječje privrženosti}

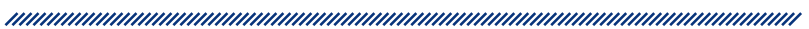

Dijete uspostavlja vezu s najbližom osobom. Najčešće su to roditelji, koji će mu svojom blizinom i dostupnošću osigurati zaštitu. U situacijama koje doživi kao nesigurne i prijeteće dijete traži zaštitu roditelja kroz privrženo ponašanje. Većina djece, oko dvije trećine, uspostavlja siguran tip privrženosti. Roditelj takvog djeteta emocionalno je dostupan, tj. u pravo vrijeme i na pravi način odgovara na djetetove razvojne i emocionalne potrebe. Djeca čiji roditelji nisu uspjeli na zadovoljavajući način odgovarati na njihove potrebe svijet doživljavaju kao nesigurno mjesto, uskraćeni su za iskustva koja im omogućuju razvoj samopouzdanja i povjerenja u druge te razvijaju nesiguran tip privrženosti koja se u odrasloj dobi može očitovati kroz uspostavljanje površnih odnosa, nekritično uspostavljanje emocionalnih odnosa, nepovjerenje, autodestruktivnost ili heterodestruktivnost, nedostatak morala i samokontrole, agresiju i dr. Vulnerabilnost djeteta stanje je najmanje otpornosti na oštećenja i agresiju, 
a rezultat je interakcije genskih i okolinskih čimbenika. Očituje se kao predispozicija za somatsko ili psihičko disfunkcioniranje ${ }^{13}$. Jedan su od rizičnih čimbenika za razvoj nesigurne privrženosti i depresivni poremećaji roditelja, bilo jednog ili oba, gdje je dokazano da oni kao takvi pokazuju manje prihvaćanja, topline, spontanosti i strpljivosti te su skloniji učestalijem kažnjavanju djece. Bolesni član obitelji mijenja ustaljene odnose i rituale, ovisno o tome koju poziciju zauzima u obitelji. U slučaju bolesti majke obitelj kratkoročno uglavnom uspijeva kompenzirati novonastalu situaciju, dok kod dugotrajnih procesa dolazi do trajnih promjena unutar obitelji i često ženska djeca mogu biti zakočena u svojem razvoju zbog poremećenog procesa identifikacije. Kod bolesti oca, koji u strahu od narcističke povrede da više ne može adekvatno skrbiti o obitelji može prihvatiti ili odbiti pažnju obitelji, u svakom slučaju briga i odgovornost prelaze na ostale članove obitelji, među njima i djecu ${ }^{10}$.

\section{Posljedice odrastanja uz depresivne roditelje}

Djeca čiji roditelji nisu adekvatno odgovorili na njihove emocionalne potrebe donose zaključke da su loši, neželjeni, bezvrijedni te da ne mogu imati povjerenja u roditelje i na tim temeljima grade svoje buduće odnose. Ta negativna temeljna uvjerenja potiču osjećaj emocionalne otuđenosti i izolacije od obitelji i društva. Prema Beckovoj kognitivnoj teoriji, depresivne se osobe osjećaju tako zato što je njihovo razmišljanje pristrano usmjereno na negativna tumačenja. Prema Becku, u djetinjstvu i adolescenciji depresivne osobe stječu negativnu shemu, između ostalog i zbog depresivnog stava roditelja. Lewinsohn objašnjava nastanak depresivnog poremećaja u djece kao posljedicu nezadovoljavajućega pozitivnog potkrepljivanja, što stvara osjećaj bespomoćnosti i uvjerenje kako se ne može utjecati na okolinu, dok ga Seligman definira kao naučenu bespomoćnost ${ }^{17}$. Budući da takvoj djeci roditelji nisu uspjeli osigurati zadovoljenje potreba, osjećaju se nevidljivo i bespomoćno, što postaje uobičajeni način mišljenja i osjećanja u budućnosti. Ako dijete povjeruje da ne dobiva zadovoljenje osnovnih potreba kad to treba i traži, agresivno ponašanje i neprimjereni ispadi bijesa mogu mu se učiniti kao jedino rješenje. Takvo ponašanje može biti kratkoročno učinkovito i održati povezanost $\mathrm{s}$ roditeljem, makar samo konfliktnu, ali pridonijeti i razvoju odbijajućih roditeljskih reakcija, čime se dodatno prekida mogućnost uspostave zdrave veze. Drugim riječima, ako dijete jedino neprimjerenim reakcijama dobiva pažnju roditelja, to postaje ustaljeni obrazac ponašanja.

Regulacija emocija i ponašanja ključna je u zdravom ranom razvoju djece, gdje ono u interakciji s okolinom uči prilagođavati emocije, nositi se s frustracijom i stresom. Roditelji koji su depresivni te nisu usklađeni s djetetovim potrebama i emocijama ostavljaju ga bez potpore da upravlja svojom ljutnjom, tugom i strahovima te će biti prepušteno vlastitom nezrelom repertoaru ponašanja. Bolesna majka ne može adekvatno odgovoriti na djetetove potrebe te će ono majku koja ne ispunjava njegova očekivanja doživjeti kao i da nije prisutna ${ }^{10}$. Takvo zanemarivanje dovodi do nesposobnosti djece da prepoznaju svoje emocije i ponašanje i njima upravljaju. Budući da dijete roditeljske vrijednosti i ponašanja usvaja kao vlastita, tako se može očekivati da transgeneracijskim prijenosom usvoji neosjetljivost za zadovoljenje potreba vlastite djece u budućnosti ${ }^{18}$.

Prema istraživanju Medicinskog fakulteta sveučilišta u New Yorku provedenom na više od 20000 obitelji, $11 \%$ djece s depresivnim očevima, $19 \%$ djece s depresivnim majkama te $25 \%$ djece u slučajevima kad su oba roditelja patila od depresivnog poremećaja imalo je ponašanje koje se karakterizira kao problematično te neprimjereno emotivno funkcioniranje, dok je takve djece koja dolaze iz obitelji gdje roditelji ne boluju od depresivnog poremećaja bilo svega $6 \%$. Istraživanje provedeno na uzorku od 69 majki praćenih od početka trudnoće pa do trideset mjeseci postpartalno pokazalo je da majke s depresivnim poremećajem kao komorbidnom dijagnozom pružaju manje pažnje i skrbi od majki bez poremećaja ili samo s depresivnim poremećajem ${ }^{19}$.

\section{Zaključak}

Svakodnevni se obiteljski život mijenja i postaje kompliciraniji kada roditelj pati od depresivnog poremećaja. Nesigurnost povezana s neizvjesnošću i tijekom bolesti utječe na svakodnevni život ukućana. Takav poremećaj mijenja vezu između roditelja i djece jer dolazi do otežane komunikacije. Depresivni se roditelj povlači u sebe, a djeca imaju osjećaj da su prepuštena sama sebi. Odgoj i 
naslijeđe osnovni su čimbenici koji formiraju ličnost. Dok je genetsko „opterećenje“ depresivnim poremećajem $30 \%{ }^{20}$ nešto što je konstanta, odgoj je ono na što se može utjecati jer su roditelji najvažniji modeli u ranom razvoju te njihove metode odgoja postavljaju temelj buduće ličnosti u koje će dijete izrasti. Zdravstveni djelatnici koji skrbe o oboljelom zapravo neizravno pozitivno utječu i sudjeluju i u odgoju njegove djece. S obzirom na to da depresivni poremećaj ima kompliciran utjecaj na već izgrađenu ličnost oboljelog roditelja i njegovu okolinu, postavlja se pitanje kakav je utjecaj na vulnerabilnu ličnost djeteta oboljeloga. Depresivni poremećaj utječe na sve članove obitelji, stoga je kod odraslih osoba koje imaju malodobnu djecu što ranija detekcija i primjereno liječenje pomoć ne samo njima, oboljelima, nego još i značajnije, njihovoj djeci. Dječji poremećaji traže rane, sveobuhvatne i dugotrajne intervencije s ciljem da budu proaktivne, a ne reaktivne, kad se problem već dogodi. Osim roditeljske patologije, na nastanak poremećaja utječu i drugi faktori, poput ekonomskih ili socijalnih koji su čest pratitelj obiteljske disfunkcionalnosti, pa bi intervencije, da bi bile učinkovitije, morale djelovati na više tih faktora. Jedne su od učinkovitijih kognitivno-bihevioralne, koje se primjenjuju ne samo kod dječje anksioznosti i depresivnosti već impulzivnosti i hiperaktivnosti, tj. onih poremećaja koji uglavnom i prate djecu koja odrastaju u depresivnom okruženju, kojima ih se podučava kako da svoje neprikladno ponašanje racionalno kontroliraju ${ }^{21}$. Potrebna je pomoć roditelja, socijalnih radnika i patronažnih sestara, uključivanje u sustav zdravstvenog odgoja i detekcija potrebne razine skrbi, u svakom slučaju, aktivnije djelovanje i multidisciplinarni pristup, kako bi se smanjio ili ublažio eventualni transgeneracijski prijenos bolesti, jer se način emocionalne relacije između roditelja i djece, dakako, uz uvijek nove modifikacije, prenosi iz generacije $u$ generaciju ${ }^{22}$.

\section{Literatura}

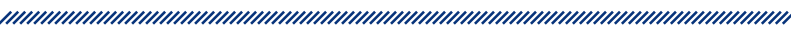

1. Jakovljević M. Depresivni poremećaji: Od ranog prepoznavanja do uspješnog liječenja. Zagreb: Pro Mente; 2004.

2. Davey G. Psychopathology: research, assessment and treatment in clinical psychology. Chichester: Blackwell; 2008.

3. Akiskal HS. New insights into the nature and and heterogeneity of mood disorders. Journal of Clinical Psychiatry. 1989;50 Suppl.: 6-10.

4. Caspi A, Sugden K, Moffitt TE, Taylor A, Craig IW, Harrington H, McClay J, Mill J, Martin J, Braithwaite A, Poulton R. Influ- ence of life stress on depression: moderation by a polymorphism in the 5-HTT gene. Science. 2003;301(5631):386-389.

5. Lopez Leon S, Croes EA, Sayed-Tabatabaei FA, Claes S, Van Broekhoven C, van Duijn CM. The dopamine D4 receptor gene 48-base-pair repeat polymorphism and mood disorders: A meta-analysis. Biological Psychiatry. 2005;57(9):999-1003.

6. Freud S. Mourning and melancholia. Collected papers. Vol. 4. London: Hogarth; 1917.

7. Beck AT. Depression: Causes and treatment. Philadelphia: University of Pennsylvania Press; 1967.

8. Lewinsohn PM. A behavioral approach to depression. U: Friedman RJ, Katz MM, ur. The psychology of depression: Contemporary theory and research. Washington DC: Winston-Wiley; 1974.

9. Holmes TH, Rahe RH. The Social Readjustment Rating Scale. Journal of Psychosomatic Research. 1967;11(2):213-218.

10. Klain E i sur. Psihološka medicina. Zagreb: Golden marketing; 1999.

11. Lebedina Manzoni M. Psihološke osnove poremećaja u ponašanju. Jastrebarsko: Naklada Slap; 2007.

12. Biloglav M, Skorić V, Rudan S, Odgoj ili genetika - nadrastanje vlastitog nasljeđa. Ekvilibrij - Časopis studenata pedagogije Hrvatske. 2012;1. Dostupno na: http://www. pedagogija.hr/ekvilibrij/pdf/odgoj-ili-genetika.pdf (pristupljeno 04.09.2015.)

13. Nikolić S, Marangunić M i sur. Dječja i adolescentna psihijatrija. Zagreb: Školska knjiga; 2004.

14. Macuka I. Osobine i kontekstualne odrednice roditeljskog ponašanja. Suvremena psihologija. 2010;13(1):63-81.

15. Tronick E, Reck C. Infants of depressed mothers. Harvard review of psychiatry. 2009;17(2):147-156.

16. Dix T, Meunier LN. Depressive symptoms and parenting competence: An analysis of thirteen regulatory processes. Developmental Review. 2009;29:45-68.

17. Berger J, Biro M, Hrnjica S. Klinička psihologija - individualna i socijalna. Beograd: Naučna knjiga; 1990.

18. Buljan Flander G, Bačan M, Matešković D. Nasilna ponašanja mladih - Zašto je ljubav važna? Zagreb: Poliklinika za zaštitu djece Grada Zagreba; 2010. Dostupno na: http:// www.poliklinika-djeca.hr/wp-content/uploads/prirucnikzasto-je-ljubav-vazna.pdf (pristupljeno 04.09.2015.)

19. Carter AS, Garrity-Rokous FE, Chazan-Cohen R, Little C, Briggs-Gowan MJ. Maternal depression and comorbity: predicting early parenting, attachment security, and toddler social-emotional problems and competencies. Journal of the American Academy of Child and Adolescent Psychiatry. 2001;40(1):18-26.

20. Agrawal A, Jacobson KC, Gardner CO, Prescott CA, Kendler KS. Population-based twin study of sex differences in depressive symptoms. Twin Research. 2004;7(2):176-181.

21. Nietzel MT, Bernstein DA, Milich R. Uvod u kliničku psihologiju. Jastrebarsko: Naklada Slap; 2002.

22. Blažević D, Cividini-Stranić E, Beck-Dvoržak M. Medicinska psihologija. Zagreb: Jugoslavenska medicinska naklada; 1979. 


\section{THE EFFECT OF PARENTAL DEPRESSION ON A CHILD'S DEVELOPMENT}

1 Boris Vučić

1 Samka Ekić

${ }^{1}$ Clinic for Psychiatry, Clinical hospital Dubrava, Zagreb, Croatia

\section{Abstract}

Mood disorders are among the most common psychiatric disorders and the incidence of depressive disorders is on the rise. A depressive disorder deeply permeates every aspect of life and affects the whole family. We can thus say that the disease of the individual takes effect on the whole family, especially its most vulnerable members. As there is no age limit for the occurrence of depression, the question is how this disease affects children, that is, how growing up with a depressed parent influences the child's psychosocial development and formation of personality. 